\title{
Risk Governance Structure and Firm Performance: An (Exploratory) Empirical Study in Indian Context
}

\author{
M.V. Shivaani
}

Indian Institute of Management (IIM) Nagpur, India

\begin{abstract}
The study attempts to explore the relationship between risk governance structure and firm performance. In perhaps the first of its kind attempt, a normative framework for risk governance structures is being put forward. Based on the framework, an index indicating strength/quality of risk governance structures is proposed. Then, the impact of risk governance structure on firm performance is gauged. To this end, the study makes use of constituents of S\&P CNX500 index and covers a ten year period from April 1, 2005 to March 31, 2015.To control for potential endogeneity among variables of interest, the study makes use of a robust and reliable methodology, 'difference-GMM'. In addition, to ensure completeness of results, the study employs control variables such as recession dummy, firm's age, size, and growth rate and leverage ratio. The results suggest that robust risk governance structures do not necessarily lead to better firm performance. In fact, risk governance index is negatively related to both ROA and ROE. The relationship is not statistically significant but has wide economic implications. A prominent implication being, mere constitution of risk management committee and appointment of CRO will not improve firm performance; regulators and companies need to ensure that governance structures are not too rigid, excessively risk averse and ineffective and inefficient in decision making. Given the simplicity and reliability of the proposed risk governance index, and the recommendations put forth in the paper, the study is expected to be of immense utility in an important yet neglected area of risk governance.

Keywords: Risk Governance; ROA; ROE; Difference-GMM
\end{abstract}

\section{Introduction}

One of the basic objectives of business is to generate sufficient returns for its various stakeholders, particularly, shareholders and lenders of long-term finance. But, this objective is fraught with risks (internal as well as external). Since a company is an artificial person, the responsibility of both management of these risks and direction and supervision of the company vests with Directors. Therefore, the structure and composition of Board of Directors become significant factors in determining the success of risk management in a firm.

In addition, every organization has separation of ownership and control. This invariably leads to agency problems (Jensen and Meckling, 1976). Management may be inclined to waste shareholders' resources to satisfy its exploitative purposes. Therefore, any excessive risk taking may only be curbed through an effective and efficient risk governance mechanism, which in turn depends on a robust and resilient risk governance structure.

The literature is rife with corporate governance indices and their relationship with different business parameters like risk, return, profitability, etc. But,few studies focus on risk governance and risk structure. Further, the available studies are largely in context of financial entities. Therefore, the study is perhaps the first of its kind with the focus on risk governance in non-financial entities.

Further, an efficient risk governance structure is believed to be pivotal in setting tolerable risk limits, appropriate risk-appetite standards, risk policy, and risk culture in an organization. Recognizing this importance of risk governance, the study proposes a normative framework for risk governance structure and then goes on to gauge the impact of this structure on firm performance.

Copyright (C) 2018 M.V. Shivaani

doi: $10.24294 /$ fsj.v1i4.942

EnPress Publisher LLC.This work is licensed under the Creative Commons Attribution-NonCommercial 4.0 International License (CC BY-NC 4.0).

http://creativecommons.org/licenses/ by/4.0/ 
A number of studies document that certain governance structures may be drivers of firm performance, but these studies have been widely criticised as most of them tend to ignore potential endogeneities. Critics argue that there is a possibility (of reverse causality) that performance drives governance or some third unobservable factor influences both governance and performance (Wintoki, et al., 2012). Recognising this (potential) endogenous nature of relationship between corporate governance and firm performance, Bhagat and Black (2002), suggest unreliability of estimation techniques that overlook this pertinent issue. Following this stream of thought, Wintoki, et al. (2010), advocate use of generalized method of moments (GMM), technique that is aptin dealing with endogeneity and simultaneity bias.

Therefore, the study uses 'difference GMM' with control variables to gauge the relationship between risk governance structure and firm performance.

The paper has been organized into seven sections. Section 2 highlights relevance of risk governance. Section 3 describes the sample used and sources of data. Section 4 elaborates the methodology employed for index construction and for analysis. Section 5 examines the findings and presents the analysis of the same. This is followed by concluding observations.

\section{Background and review of literature}

With international organizations such as Financial Stability board (FSB, 2013)and Committee of Sponsoring Organization (COSO) (COSO,2013) focusing extensively on risk governance, it seems imperative to review that whether the structures based on recommendations provided in these guidelines are actually serving their intended purpose or not. These studies are particularly required for emerging countries (such as India and China) that are in transitory phase in terms of governance reforms. It will help policy makers and regulators in examining that whether the regulations are actually making any contribution or not and that whether the compliance with the regulations is a mere eyewash. Further, the concept of risk governance being a recent phenomenon is narrowly researched; whatever research exists is mainly for financial entities.

Corporate governance and firm performance is a widely researched phenomenon, with results ranging from positive association (Brookman and Thistle, 2009; Pan et al., 2013)to negative association (Bebchuk et al., 2009). In fact few studies have documented no relation also. It is worth mentioning that not just corporate governance (Noor and Ayoub, 2009) and related measures, but also other firm specific factors like age, size, leverage (Mancinelli and Ozkan, 2006), growth (Damodaran, 2006), DPS (Kamunde, 2011), etc. could be significant factors affecting firm performance.

In a recent study, Abu-Ghunmi et al. (2015) emphasized that corporate governance mechanisms not only affect firm performance but could provide plausible explanation for idiosyncratic risk also. Their arguments are in line with those of Baxter and Cotter (2009) and Davidson et al. (2005), who evidenced that composition of audit committee and proportion of non-executive directors, are significant contributors towards improvement in earnings quality. In a similar study Huang and Wang (2015) emphasized the importance of board size for firms' riskiness.

Unlike most studies, that have linked specific governance indicators with firm's riskiness, Jiraporn et al. (2015) explored the relationship between governance and risk by using a composite governance indicator. They consider two contrasting hypothesis; first, risk-avoidance hypothesis and second, risk-seeking hypothesis. In the context of risk-avoidance view, they posit that weak governance structures result in lower risk taking. Pursuing the risk-seeking hypothesis Lee et al. (2006) suggest that better governance may reduce firm specific risks.

It is noteworthy that there are empirical evidences and studies focusing on corporate governance and risk, but, no particular study focusing on risk governance could be found. Also, in terms of corporate governance, the studies have either looked at specific governance mechanisms (like, CEO duality, board size, audit committee composition, etc.) or existing composite governance measures like GIM-index, developed by Gompers et al. (2003).

It is pertinent to note, that corporate governance has varying definitions and encompasses a plethora of variables, whose relevance varies as per the context. In the context of risk and risk taking, focus needs to be put on a specialized subset of corporate governance, called risk governance. Risk governance has been defined as "the ways in which 
directors authorize, optimize, and monitor risk taking in an enterprise. It includes the skills, infrastructure (i.e., organization structure, controls and information systems), and culture deployed as directors exercise their oversight" (International Finance Corporation (IFC). Since, risk governance is the specialized arm of corporate governance that deals exclusively with risk and risk management, it appears reasonable to believe that the quality of governance structure would have an impact on the firm performance, which could be viewed as function of risk levels of the company.

In view of the above, the primary purpose of the paper is to explore the relation between risk governance structure and firm performance. In other words, study attempts to gauge whether better risk governance structure leads to better firm performance.

\section{Sample}

The sample consists of non-financial companies that constitute CNX 500 index as on March 31, 2014. The study covers a period of 10 years from April 1, 2005 to March, 31, 2015. It is noteworthy that the sample covers 15 industries, namely, agriculture, capital goods, chemical, diversified, fast moving consumer goods (FMCG), healthcare, housing, information and communication technology (ICT), media, metal, miscellaneous, oil and gas, power, textile and transport.

\section{Methodology}

The main objective of the paper is to gauge whether better risk governance structure leads to better firm performance. Therefore, as a first step, risk governance index (RGI) (which will be the independent variable) has been developed. The index is based on ninevariables, namely, size of board, board diversity in terms of gender, proportion of executive directors, executive/non-executive status of Chairperson, proportion of independent directors, CEO duality, existence of Chief risk officer (CRO), risk management committee, and whistle blower policy. These variables are scored on a scale of 1 to 5 with the exception of the variables, namely, status of Chairperson and CEO duality (which have been scored on a dichotomous scale with the score of 3 or 5). Further, it is worth mentioning that in respect of some of the above-mentioned variables, there are certain legal/statutory requirements under the provisions of Companies Act 2013 and/or Clause 49 of Listing agreement (entered into with SEBI)). In the case where there is a legal/statutory requirement in respect of above-mentioned variables and there is a non-compliance with such requirement a score of one has been envisaged. Though there is no legal requirement, for the larger part of study, especially in context of CRO, risk management committee and whistle blower policy, still a score of 1 has been assigned in the event of their non-existence. This view has been taken in the light of the fact that the study basically, focuses on risk governance structure. In other words, recognising the importance of these variables in context of risk governance structure, their absence has been equated to non-compliance of a legal/statutory requirement.

Therefore, based on the eleven variables the minimum score a company can have is 15 and the maximum possible is 55. For ease of comprehension, the score obtained by every company has been expressed as a percentage of maximum possible score, i.e. 55 . To illustrate, if a company scores 22 , then the index will be presented as 40 per cent i.e. $(22 / 55) * 100$.

The rationale for each of the variable has been discussed below.

\section{(1) Number of board of directors}

Boards that are below the minimum legal requirement in terms of size have been considered inappropriate by Chen et al. (2007). Jensen (1993) asserts "when boards get beyond seven or eight people, they are less likely to function effectively". Similarly, Lipton and Lorsch (1992) suggested limiting the number of directors to ten people, with an ideal of eight or nine members. Eisenberg et al. (1998) presented evidence that smaller boards are more effective.

Number of Board of Directors (BOD)

Score 


\begin{tabular}{|l|l|}
\hline $0<$ No. of $\mathrm{BOD}<3$ & 1 \\
\hline No. of $\mathrm{BOD}=3$ & 2 \\
\hline No. of $\mathrm{BOD}>15$ & 3 \\
\hline $4 \leq$ No. of $\mathrm{BOD}<8 \quad$ OR $10<$ No. of $\mathrm{BOD} \leq 15$ & 4 \\
\hline $8 \leq$ No. of $\mathrm{BOD} \leq 10$ & 5 \\
\hline
\end{tabular}

Table 1. Scoring for number of board of directors

\section{(2) Board diversity in terms of gender}

Deszo and Ross (2012) have expressed concerns about under-representation of women in upper echelons of management. Women in top management positions have been found to be more inclusive, co-operative, democratic and participatory in nature (Eagly and Johnson, 1990).

\begin{tabular}{|l|l|}
\hline Proportion of women directors on board (PoW) & Score \\
\hline No woman & 1 \\
\hline $0<\mathrm{PoW}<1 / 3$ ORPoW $>1 / 2$ & 2.5 \\
\hline $1 / 3<\mathrm{PoW}<1 / 2$ & 3.5 \\
\hline $\mathrm{PoW}=1 / 2$ & 5 \\
\hline
\end{tabular}

Table 2. Scoring in relation to number of women directors on Board

\section{(3) Proportion of executive directors}

Existence of non-executive directors on Board ensures independent judgement in times of potential conflict of interest. They are appointed to bring to Board: independence, impartiality, wide experience, special knowledge and personal qualities(Financial Stability Board, 2013).

\begin{tabular}{|l|l|}
\hline Proportion of non-executive directors on board & Score \\
\hline $0<\mathrm{PoNED}<1 / 2$ & 1 \\
\hline $\mathrm{PoNED}=1 / 2$ & 3 \\
\hline PoNED $>1 / 2$ & 5 \\
\hline
\end{tabular}

Table 3. Scoring in relation to proportion of non-executive directors

\section{(4) Executive/Non-executive chairman}

Higgs report (2003) outlines the duties of the Chairman. These include upholding standards of integrity and probity, promotion of communication between executive and non-executive directors, coherent leadership of company to name a few. Therefore, in a bid to have transparency and fairness in governance structure, it seems desirable to have a non-executive director as Board Chairman.

\begin{tabular}{|l|l|}
\hline Status of Chairman & Score \\
\hline Executive Chairman & 3 \\
\hline Non-executive Chairman & 5 \\
\hline
\end{tabular}

Table 4. Scoring in relation to Executive-non executive status of Chairman

\section{(5) Proportion of independent directors}

Boyer and Stern (2012)depict independent Boards as a good governance feature and expect firms with more independent boards to pay a lower premium. Prior studies suggest that there are some positive shareholder outcomes associated with independent boards including lower instances of earnings manipulation and fraud (Dechow et al., 1996; and Klein, 2002); superior decision making (Dahya and McConnell, 2005); and greater levels of disclosure.

When the Chairman is an executive director

\begin{tabular}{|l|l|}
\hline Proportion of independent directors on board (PoID) & Score \\
\hline
\end{tabular}




\begin{tabular}{|l|l|}
\hline $0<\mathrm{PoID}<1 / 2$ & 1 \\
\hline PoID $=1 / 2$ & 3 \\
\hline PoID $>1 / 2$ & 5 \\
\hline
\end{tabular}

Table 5. Scoring in relation to proportion of independent directors, with executive Chairman

When the Chairman is a non-executive director

\begin{tabular}{|l|l|}
\hline Proportion of independent directors on board & Score \\
\hline $0<\mathrm{PoID}<1 / 3$ & 1 \\
\hline $\mathrm{PoID}=1 / 3$ & 3 \\
\hline $\mathrm{PoID}>1 / 3$ & 5 \\
\hline
\end{tabular}

Table 6. Scoring in relation to proportion of independent directors, with non- executive Chairman

\section{(6) CEO duality}

When the CEO also serves as the Chairman of the Board, the board's ability to fulfil its supervisory function is significantly reduced due to conflict of interests (Brickley et al., 1997). Further, Rechner \& Dalton (1991) suggest absence of CEO duality facilitates effective monitoring of the activities of top management and results in reduction in agency costs. Therefore, CEO non- duality is often preferred for strategic as well as operational reasons.

\begin{tabular}{|l|l|}
\hline CEO duality & Score \\
\hline Yes & 3 \\
\hline No & 5 \\
\hline
\end{tabular}

Exhibit 7. Scoring in context of CEO duality

\section{(7) Chief risk officer (CRO)}

Appointment of a CRO is often linked with likely implementation of Enterprise-wide risk management (ERM) (Beasely et al., 2005). Further is it believed that CRO will act as a supporting pillar in development of risk management policies, frameworks and analysis.

\begin{tabular}{|l|l|}
\hline Appointed CRO & Score \\
\hline No & 1 \\
\hline Yes & 5 \\
\hline
\end{tabular}

Table 8. Scoring in context of appointment of a CRO

\section{(8) Whistle blower policy}

Implementation of a whistle blower policy and protection of whistle blowers has been advocated by several regulations and legislations worldwide (e.g.: The Public Interest Disclosure Act, 1998, in the UK; Sarbanes Oxley Act, 2002 , in the US). Whistle blowing at the right time may save the company from financial loss, scathing publicity or costs of litigation (Rotschild and Miethe, 1999).

\begin{tabular}{|l|l|}
\hline Implemented a Whistle blower & Score \\
\hline No & 1 \\
\hline Yes & 5 \\
\hline
\end{tabular}

Table 9. Scoring in context of existence of a whistle blower policy

(9) Risk management committee

\begin{tabular}{|l|l|}
\hline Risk management committee (RMC) has been & Score \\
\hline No & 1 \\
\hline Yes & 5 \\
\hline
\end{tabular}

Table 10. Scoring in context of existence of Risk management committee

\section{Control variables}


Recession- The period of study is of particular importance as it includes the recession period, which impacted the world economy towards second half of 2008. As per the United Nations Council on Trade and Development (UNCTAD), investment brief (November 1, 2009), the year 2008 marked the end of a growth cycle in global foreign direct investment. Worldwide flows came down by more than 20 per cent. This global financial crisis reduced access to financial resources internally as well as externally (Singh et al., 2012). Thus, the study considers, two phases, Phase I (pre- recession period) April 1, 2005 to March 31, 2008 (2006-2008) and April 1, 2008 to March, 31, 2015 (2009-2015) as Phase II (post-recession period). A dummy variable has been used for the purpose.

Age- Abernathy and Utterback (1978) have highlighted the significance of firms' lifecycle on strategic decisions. They suggest that younger firms have limited knowledge base and that is reflected in their governance structures. Whereas, certain other studies show that older firms exhibit rent seeking behaviour and poorer corporate governance. Further, Firm age has been linked to strategic decisions of the firm and it has been observed that complexity increases with firm age. The number of years the firm has been in existence since its inception, has been taken as the proxy for firm age.

Firm size- The effect of firm size on governance is ambiguous (Klapper and Love, 2004). It is suggested that large firms may have severe agency problems and therefore need to compensate with stricter governance mechanisms. Alternatively, small firms may have better growth opportunities and greater need for external finance, leading to better governance mechanisms. Natural log of total assets has been used to proxy size (Akbar et al 2016).

Growth- Studies havesuggested that growth rate/ growth opportunities available to a company may affect its performance. Similarly, Durnev and Kim (2003) show that growing companies, tend to exhibit higher returns to various stakeholders. Therefore, it is imperative to control for growth of company.

Leverage- Traditionally, financing pattern of a company has been viewed as a significant determiner of firm performance. The capital structure of a firm is expected to have an impact on performance, as the pecking order theory suggests a negative relation between corporate profitability and debt ratios (Fama and French, 2002). Concepts including 'trading on equity' are often employed to magnify returns for a particular group of stakeholders (Khan and Jain, 2014).

\section{Dependent variables}

Firm performance could be measured using either accounting measures or market based measures or both. The study uses accounting based measures only, as stock market based measures like stock returns could be unduly affected by investor perception (Bhagat and Bolton, 2008).

Return on assets (ROA)- It helps to understand how efficiently the funds have been appliedalsoto understand operating efficiency of firm. Though, it measures profitability of total funds, it throws no light on profitability of different sources of funds.

The use of ROA as a proxy for firm performance is quite prevalent in context of studies dealing with governance aspects (Brick et al., 2006; Cheng, 2008; Jackling and Johl, 2009; Brown and Caylor, 2005).

Return on Equity (ROE)- It helps to gauge profitability from owners/ equity shareholders' point of view (Zabria, et al., 2016). ROE is a widely accepted measure of performance (Johnson and Greening, 1999).

\begin{tabular}{ll}
\hline Variable & Measure used \\
\hline Risk governance index (RGI) & Based on normative described in Section 4 \\
Return on assets (ROA) & Net profit after taxes + Interest/ Total assets \\
Return on equity (ROE) & Net profit after taxes- Preference dividend/ Equity funds \\
Age & Years since incorporation \\
Size & Natural log of sales \\
Growth & (Current year's sales- previous year's sales)/ Previous year's sales \\
Recession & Dummy variable for pre and post-recession periods \\
Leverage & Total debt/shareholders' equity \\
\hline
\end{tabular}


Table 11. Variables and the measures used

Given the panel nature of data, panel data regression appears to be the appropriate technique. Panel data analysis provides several advantages over pooled OLS regression. It facilitates consideration of individual/firm specific heterogeneities that may be having an impact on the dependent variable, provides more informative data, more degrees of freedom and more efficiency (Baltagi, 2005). Further, Wintoki et al. (2010) suggest three potential sources of endogeneity that may exist in panel data structures: (i). Dynamic endogeneity- it occurs when the preceding periods' values of a variable influence its current period values. This form of endogeneity has been often observed in studies dealing with corporate governance- performance relationship (Hermalin and Weisbach, 1998). (ii).Simultaneity- It occurs when two variables simultaneously affect each other, resulting in their co-determination. (iii).Unobserved heterogeneity- It is phenomenon where the relationship between two variables is affected by some third unobservable variable. In general, these may be attributed to firm-specific characteristics or firm-fixed effects (Haubrich and Ritter, 1996).

The most common solution to deal with endogenetity problems is the use of lagged dependent variables or instrumental variables. The estimation techniques that may be employed are OLS, FE or DPD GMM. If OLS is used for estimation, it typically results in an upward bias in the coefficient of lagged dependent variable (Bond, 2002). Similarly, in the context of unobservable firm heterogeneities, Baltagi (2008) discourages the use of fixed effects model (particularly, when the panel is a short panel). He suggests that the lagged dependent variable may end up being correlated with error-term, resulting in biased coefficients. Further, the coefficients of the lagged dependent variable, obtained through FE estimation may have a downward bias (Nickel, 1981).To overcome these problems Holtz-Eakin $e t$ al. (1988) proposed generalized method of moments (GMM) panel specifications, which was later popularised by Arellano and Bond (1991), Arellano and Bover (1995) and Blundell and Bond (1998). They suggest that the problems of endogeneity may be overcome by developing valid instruments which will result in unbiased and consistent coefficients. It is worth mentioning that Arellano and Bond (1991), first-difference the panel data to remove the time-invariant fixed effect and show that the lagged dependent variables' values (levels)constitute legitimate instruments for the first-differenced variable; provided that the residuals are free from second-order serial correlation.

The validity of instruments is gauged by using the Sargan test of over-identifying restrictions. Further, a test is conducted to ensure there is no serial correlation (of order two) among the transformed error terms.

The decision to use Arellano Bond (1991)- 'difference GMM' -for the current study is based on the findings of (Larcker\&Rusticus, 2010; Petersen, 2009). They suggest that companies are unique in terms of their strengths and weaknesses. This can result in a scenario whereby disclosure and governance practices are jointly and dynamically determined by unobserved company-specific heterogeneities, such as managerial talent, corporate culture and complexity (Guest, 2009; Henry, 2008), which simple OLS regressions may be unable to detect (Gujarati, 2003; Wooldridge, 2010). In addition, Hermalin and Weisbach (2003), Himmelberg et al. (1999), and Denis and Kruse (2000) argue that firm performance and corporate governance are simultaneously determined by unobservable firm-specific factors, and that governance changes are determined by past, present and/or expected characteristics of the firm.

Hence, given the panel nature of data and following past studies, the study proposes to use 'difference GMM' for estimating various relationships.

\section{Empirical evidence}

It is evident from Table 2 that the mean index score for the period of study is about 65 per cent; this may be attributed to increased focus on corporate governance and risk management. Further, the index score in the range of about $65 \%$ per cent is indicative of most (governance) parameters being in the range of 3 to 4 (out of 5) each. In other words, on an average, Indian companies have a near ideal index, based on the normative framework developed above. In addition, a low standard deviation in the range of 8-9 per cent is suggestive of somewhat similar structures in majority of companies.In sum, the Indian corporate sector appears to be mindful of the benefits of strong governance 
structure. They seem to have the belief that it's the governance structure and mechanism that will enable companies to manage risks, endure difficulties and leverage the opportunities.

\begin{tabular}{llllllll}
\hline Variable & N & Minimum & Maximum & Mean & $\begin{array}{l}\text { Std. } \\
\text { Deviation }\end{array}$ & Skewness & Kurtosis \\
\hline Growth & 3301 & -1.00 & 110.79 & 0.13 & 2.56 & 32.35 & 1228.27 \\
Age & 3301 & 2.00 & 152.00 & 37.90 & 24.40 & 1.35 & 2.13 \\
CGI & 3301 & 0.40 & 0.87 & 0.65 & 0.08 & -0.14 & -0.16 \\
Leverage & 3301 & -10.45 & 100.02 & 1.47 & 2.51 & 24.59 & 866.52 \\
ln(sales) & 3301 & -2.41 & 13.07 & 7.43 & 1.52 & 0.05 & 2.22 \\
ROA & 3301 & -0.48 & 0.63 & 0.152 & 0.09 & 0.83 & 3.87 \\
ROE & 3301 & -44.07 & 5.17 & 0.146 & 0.80 & -51.25 & 2838.93 \\
\hline
\end{tabular}

Table 12. Descriptive Statistics of relevant variables

It is noteworthy that the sample adequately represents both young and old \&established companies, with an average age of about 38 years for the sample companies. Similarly, the sample is representative in terms of size of company. Further, given the fact these are India's top non-financial companies; an average growth rate of $13 \%$ over the period of study is not surprising. A leverage ratio of around 1.5 indicates that on an average these sample companies rely more on outside liabilities than shareholders' funds.

Both the dependent variables, measures of firm performance, have a mean of about 15 per cent. Though ROA $(15.2 \%)$ is slightly higher than ROE $(14.6 \%)$, it is markedly less dispersed among companies than ROE. This clearly implies that companies vary significantly in terms of their ability to generate returns for equity shareholders; nonetheless, companieshave similar operating efficiencies.

To understand the factors that drive these performance measures, panel data regression with 'difference GMM' has been employed. The equations can be written as:

$$
\begin{aligned}
& R O A_{i t}=\alpha+R O A_{i, t-1}+R G I_{i t}+\text { Age }_{i, t}+\text { Size }_{i, t}+\text { Growth }_{i, t}+\text { Recessiondummy }_{i, t}+\text { Leverage }_{i, t}+\varepsilon_{i, t} \\
& R O E_{i t}=\alpha+R O E_{i, t-1}+R G I_{i t}+\text { Age }_{i, t}+\text { Size }_{i, t}+\text { Growth }_{i, t}+\text { Recessiondummy }_{i, t}+\text { Leverage }_{i, t}+\varepsilon_{i, t}
\end{aligned}
$$

Table 3 reveals that current levels of return on assets are significantly and positively affected by return on assets realised in immediately preceding previous year. Surprisingly, there is a negative relationship between risk governance index and ROA. This implies that better the governance structure, poorer the firm performance. Though this relationship is not statistically significant, it has wide economic implications. This could possibly mean that seemingly good governance structures do not necessarily imply effective governance. In other words, good governance structures may not always translate into better decisions. It is noteworthy, Arora and Sharma(2016), found similar results in Indian context.

It is worth mentioning that few control variables such as age of firm, size of firm and period of recession seem to have a statistically significant impact on ROA of Indian firms. On one hand as the firms survive more years they tend to gain more operating efficiency, on the other hand, as firms increase in size, they tend to exhibit lower ROA. Further, recession seems to have adversely affected the firms' capacity to generate ROA.

Table 4 reveals that current levels of return on shareholders' equity are significantly and positively affected by ROE observed in immediately preceding previous year. Surprisingly, there is a negative relationship between risk governance index and ROE. This implies that better the governance structure, lower the returns generated on funds provided by equity shareholders. Though this relationship, like that of ROA and governance structures, is not statistically significant, it has extensive economic implications. The negative relationship seems to suggest that may be 
the governance structures though strong, prima facie, are too rigid. These structures are probably acting as impediments to effective and efficient decision-making; they seem to be facilitating acceptance of safer non-yielding alternatives over that of risky but rewarding opportunities. In other words, these structures appear to propagate the culture of risk avoidance, possibly leading to passing- on of risky yet potentially rewarding projects. The results are similar to that of Arora and Sharma(2016), who found that ROE of Indian firms are not related to corporate governance indicators.

\begin{tabular}{llll}
\hline Variables & Coefficient & error & p-value \\
\hline ROA t-1 & 0.162330 & 0.056800 & $0.004^{* * *}$ \\
RGI & -0.013748 & 0.019700 & 0.487 \\
Age & 0.001756 & 0.005849 & $0.003^{* * *}$ \\
Growth & -0.000751 & 0.000701 & 0.284 \\
Size & -0.493012 & 0.005524 & $0.000^{* * *}$ \\
Leverage & -0.000068 & 0.000521 & 0.896 \\
Prepost & -0.005990 & 0.003440 & $0.082^{*}$ \\
cons & 0.463434 & 0.042506 & $0.000^{* * *}$ \\
Number of observations & & 2362 & \\
Number of instruments & & & \\
& & Statistic & p-value \\
Wald test & $\chi 2(26)$ & 181.420 & $\mathbf{0 . 0 0 0 0} * * *$ \\
Sargan test & $\chi 2(35)$ & 41.806 & 0.199 \\
Autocorrelation & First order & -3.792 & 0.000 \\
& Second order & -1.498 & 0.134 \\
\hline \multicolumn{5}{c}{$* * *$ Significant at $1 \%$ level; $*$ Significant at $10 \%$ level }
\end{tabular}

Table 3. Results of (Arellano-Bond) GMM estimation of ROA on first lag of ROA and RGI and control variables

\begin{tabular}{llll}
\hline Variables & Coefficient & Standard error & p-value \\
\hline ROEt-1 & 0.279458 & 0.302726 & $0.000^{* *}$ \\
RGI & -0.380374 & 0.108016 & 0.725 \\
Age & -0.033227 & 0.008218 & $0.000^{* * *}$ \\
Growth & -0.001851 & 0.001123 & $0.099^{*}$ \\
Size & 0.193335 & 0.056147 & $0.001^{* * *}$ \\
Leverage & -0.255999 & 0.025428 & $0.000^{* * *}$ \\
Prepost & -0.043379 & 0.014277 & $0.002^{* * *}$ \\
cons & 0.245806 & 0.252582 & 0.330 \\
Number of observations & & 2362 & \\
Number of instruments & & 43 & \\
& & Statistic & p-value \\
Wald test & $\chi 2(26)$ & 289.230 & $0.0000^{* * *}$ \\
Sargan test & $\chi 2(35)$ & 38.033 & 0.325 \\
Autocorrelation & First order & -2.159 & 0.031 \\
& Second order & 1.331 & 0.183 \\
\hline
\end{tabular}

$* * *$ Significant at $1 \%$ level; **Significant at $5 \%$ level $; *$ Significant at $10 \%$ level

Table 4. Results of (Arellano-Bond) GMM estimation of ROE on first lag of ROE and RGI and control variables Interestingly, all the control variables are statistically significant in context of ROE. In contrast to results of ROA, 
age is negatively related with ROE, i.e. younger firms tend to generate higher return for their equity shareholders. Similarly, in terms of size, bigger firms seem to have higher ROE than smaller firms. Further growth and leverage are negatively related to ROE. Just as in the case of ROA, recession has had a negative impact on ROE as well.

These surprising yet interesting findings call for a review of policies (regulatory), policies those prima facie seem to strengthen risk governance structures and facilitate effective and efficient decision making but, in reality fail to yield the desired/intended results.

\section{Concluding observations}

Literature is rife with corporate governance studies and various versions of corporate governance index are available. But, construction of a risk governance index (as proposed in this study) is perhaps the first of its kind attempt.

Indian companies have decent risk management structure with mean index scores of about 65 per cent. The general view is that a good risk governance structure is pertinent for effective and efficient risk management and better firm performance, but, results indicate the contrary. To overcome the problem of endogeneity and simultaneity bias the relationship between governance structure and firm performance has been gauged using a robust estimation technique, 'difference GMM'. The results show that booth ROA and ROE are negatively related to risk governance index, indicating that better the governance structure, poorer the firm performance. This is suggestive of rigid structures and/or inefficient decision making. Regulators need to take cognizance of the fact that mere constitution of risk management committee or appointment of a CRO is not going to ensure better risk management and improved firm performance. Directors and CRO and risk management committee should be competent and effective.

It is noteworthy that both ROA and ROE are significantly affected by the respective measures of immediately preceding previous year. Further, firms' age, size, growth rate, leverage ratio and recession affect ROA and ROE in varying degrees.

In addition,the study is believed to have important implications for regulators, investors as well as for management of companies.

In sum, better governance structures do not necessarily ensure better risk management and improved firm performance.

\section{References}

1. Abernathy WJ, Utterback, James, M. Patterns of industrial innovation. Technology Review 1978; 80 (7): $40-72$.

2. Abu Ghunmi D., Adel B, Tyeh M. Idiosyncratic risk and corporate governance: evidence from jordan. Emerging Markets Finance and Trade 2015; 51(4): 40-50

3. Akbar S, Hughes JP, Ramadan EL-Faitfouri, Shah SZA. More on the relationship between corporate governance and firm performance in UK: Evidence from the application on generalised methods of moments estimation. Research in International Business and Finance 2016; 38: 417-429.

4. Arellano M, Bond S. Some tests of specification for panel data: montecarlo evidence and an application to employment equations. The Review of Economic Studies 1991; 58 (2): 277-297.

5. Arellano M, Bover O. Another look at the instrumental variable estimation. Journal of Econometrics 1995; 68 (1): 29-51.

6. Arora A, Sharma C. Corporate governance and firm performance in developing countries: evidence from India. International Journal of Business in Society 2016; 16 (2): 420 - 436.

7. Baltagi BH. Forecasting with panel data. Journal of Forecasting 2008; 27 (2): 153-173.

8. Baltagi BH. Econometric Analysis of Panel Data (third ed.) John Wiley\&amp; Sons. 2005.

9. Baxter P, Cotter J. Audit committees and earnings quality. Accounting \&amp; Finance 2009; 49 (2): $267-290$.

10. Beasley MS, Clune R, Hermanson DR. Enterprise risk management: An empirical analysis of factors associated with the extent of implementation. Journal of Accounting and Public Policy 2005; 24 (6): 521-531.

11. Bebchuk L, Cohen A, Ferrell A. What matters in corporate governance? Review of Financial Studies 2009; 22(2): 783-827.

12. Bhagat $\mathrm{S}$, Black Bernard $\mathrm{S}$. The non-correlation between board independence and long-term firm performance. Journal of Corporation Law 2002; 27: 231-273.

13. Bhagat, S., \&amp; Bolton, B. (2008). Corporate governance and firm performance. Journal of Corporate Finance, $14(3), 257-273$.

14. Blundell, R.,\&amp; Bond, S. (1998). Initial conditions and moment restrictions in dynamic panel data models. 
Journal of Econometrics ,87 (1), 115-143.

15. Bond Stephen. Dynamic panel data models: a guide to micro data methods and practice. Cemmap working paper cwp09/02. The institute for fiscal studies department of economics, UCL 2002.

16. Boyer MM, Stern LéaH. Is corporate governance risk valued? Evidence from directors' and officers' insurance. Journal of Corporate Finance 2012; 18 (2): 349-372.

17. Brick IE, Palmon O, Wald JK. CEO compensation, director compensation, and firm performance: Evidence of cronyism? Journal of Corporate Finance 2006; 12 (3): 403-423.

18. Brickley JA, Coles JL, Jarrell G. Leadership structure: separating the CEO and Chairman of the board. Journal of Corporate Finance 1997; 3(3): 189-220.

19. Brookman J, Thistle PD. CEO tenure, the risk of termination and firm value. Journal of Corporate Finance 2009; 15(3): 331-344 .

20. Brown LD, Caylor ML. Corporate governance and firm valuation. Journal of Accounting and Public Policy 2006; 25(4): 107-155.

21. Chen A, Kao L, Tsao M, et al. Building a corporate governance index from the perspectives of ownership and leadership for firms in Taiwan. Corporate Governance 2007; 15(2): 251-261.

22. Cheng S. Board size and the variability of corporate performance. Journal of Financial Economics 2008; 87(1): $157-176$.

23. Dahya J, McConnell JJ. Outside directors and corporate board decisions. Journal of Corporate Finance 2005; 11(1/2): 37-60

24. Damodaran A. Security Analysis for Investment and Corporate Finance (2nd ed.) Wiley: India 2006.

25. Davidson RJ, Stewart G, Kent P. Internal governance structures and earnings management. Accounting \&amp; Finance 2005; 45(2): 241-267.

26. Dechow PM, Sloan RG, Sweeney AP. Causes and consequences of earnings manipulation:an analysis of firms subject to enforcement actions by the sec. Contemporary Accounting Research 1996; 13(1): 1-36.

27. Denis DJ, Kruse AT. Managerial discipline and corporate restructuring following performance declines. Journal of Financial Economics 2000; 55(3): 391-424.

28. Dezsö CL, Ross DG. Does female representation in top management improve firm performance? A panel data investigation. Strategic Management Journal 2012; 33( 9): 1072-1089

29. Durnev A, Kim E. To steal or not to steal: Firm attributes, legal environment, and valuation. The Journal of Finance 2003; 60(3): 1461-1493

30. Eagly AH, Johnson BT. Gender and leadership style: a meta-analysis. Psychological Bulletin 1990; 108(2): 233-256.

31. Eisenberg T, Sundgren S, Wells M. Larger board size and decreasing firm value in small firms. Journal of Financial Economics 1998; 48 (1): 35-54.

32. Fama Eugene F, French Kenneth R. Testing trade-off and pecking order predictions about dividends and debt.The Review of Financial Studies 2002; 15(1): 1-33.

33. Financial Stability Board. Thematic review on risk governance, (February). Retrieved from http://www.financialstabilityboard.org/publications/r_130212.pdf 2013.

34. Gompers PA, Ishii JL, Metrick A. Corporate governance and equity prices. Quarterly Journal of Economics 2003; 118 (1): 107-155.

35. Guest PM. Theimpactofboardsizeonfirmperformance: EvidencefromtheUK. The European Journal of Finance 2009; 15(4): 385-404,

36. Gujarati Damodar N. Basic econometrics,. McGraw Hill 2003.

37. Haubrich JG, Ritter JA. Commitment as investment under uncertainty. Working Paper 9606, Federal Reserve Bank of Cleveland 1996.

38. Henry Anthony. Understanding Strategic Management, Oxford University Press 2008.

39. Hermalin BE, Weisbach MS. Boards of directors as an endogenously determined institution: a survey of the economic literature. Economic Policy Review 2003; 9(1): 7-26.

40. Hermalin BE, Weisbach MS. Endogenously chosen boards of directors and their monitoring of the CEO. The American Economic Review 1998; 88 (1): 96-118.

41. Higgs Report. Review of the role and effectiveness of Non-Executive Directors. London: Department of Trade and Industry 2003.

42. Himmelberg C, Hubbard RG, Palia D. Understanding the determinants of managerial ownership and the links between ownership and firm performance. Journal of Financial Economics 1999; 53: 353-384.

43. Holtz-Eakin D, Newey W, Rosen H. Estimating vector auto regressions with panel data. Econometrica 1988; 56(6): 1371-1395.

44. Huang Ying Sophie, Wang Chia-Jane. Corporate governance and risk-taking of Chinese firms: The role of board size. International Review of Economics \&amp; Finance 2015; 37(C): 96-113. 
45. Jackling Beverley, Johl Shrinjeet. Board structure and firm performance: evidence from india's top companies.Corporate Governance: An International Review 2009; 17(4): 492-509.

46. Jensen MC. The modern industrial revolution, exit and the failure of internal control systems. The Journal of Finance 1993; 48(3): 831-880.

47. Jensen MC, WH Meckling. Theory of the firm: managerial behaviour, agency cost, and ownership structure. Journal of Financial Economics 1976; 3: 305-360.

48. Jiraporn P, Leelalai V, Shenghui T. The effect of managerial ability on dividend policy: how do talented managers view dividend payouts 2015. Available at SSRN: http://ssrn.com/abstract=2681366 or http://dx.doi.org/10.2139/ssrn.2681366.

49. Johnson RA, Greening DW. The effects of corporate governance and institutional ownership types on corporate social performance. The Academy of Management Journal 1999; 42( 5): 564-576.

50. Kamunde JN. The determinants of firm value in the telecommunication sector in Kenya. Nairobi. Nairobi University 2011.

51. Khan MY, Jain PK. Financial Management (Seventh ed.). McGraw Hill Education Private Limited 2014.

52. Klapper, LeoraF.,\&amp; Love, Inessa. Corporate governance, investor protection and performance in emerging markets. Journal of Corporate Finance 2004; 10(5): 703-728.

53. Klein A. Audit committee, board of director characteristics, and earnings. management. Journal of Accounting and Economics 2002; 33(3): 375-400.

54. Larcker DF, Rusticus TO. On the use of instrumental variables in accounting research. Journal of Accounting and Economics 2010; 49(3): 186-205.

55. Lee P, René S, Roham W. Does the contribution of corporate cash holdings and dividends to firm value depend on governance? A Cross-country analysis. Journal of Finance 2006; 61( 6): 2725-2751.

56. Lipton M, Lorsch JW. A modest proposal for improved corporate governance. Business Lawyer 1992; 48(1): 59-77.

57. Mancinelli L, Ozkan A. Ownership structure and dividend policy: Evidence from Italian firms. The European Journal of Finance 2006; 12(3): 265-282.

58. Nickel S. Biases in dynamic models with fixed effects. Econometrica 1981; 49(6): 1417-1426.

59. Noor AA, Ayoib CA. Family business, board dynamics and firm value. Journal of Financial Reporting and Accounting 2009; 7(1): 53-74.

60. Pan L, Lin C, Chen K. Corporate governance and firm performance:The case of Chinese ADRs. The International Journal of Finance 2013; 25(1): 7580-7605.

61. Petersen M. Estimating standard errors in finance panel data sets: comparing approaches. Review of Financial Studies 2009; 22(1): 435-480.

62. Rechner PL, Dalton DR. Corporate board composition and capital structure :An empirical assessment. Journal of Managerial Issues 1991; 3(4): 427-444.

63. Rothschild J, Miethe T. Whistleblower disclosures and management retaliation: the battle to control information about organizational corruption. Work and Occupations 1999; 26(1): 107-128.

64. Singh S, Jain PK, Yadav Surendra S. Capital budgeting decisions: evidence from india. Journal of Advances in Management Research 2012; 9(1): 96-112.

65. Wintoki MB, Linck JS, Netter JM. 2010 Endogeneity and the dynamics of internal corporate governance. CELS 2009 4th Annual Conference on Empirical Legal Studies. Available at SSRN: http://ssm. com/abstract=970986

66. Wintoki MB, Linck JS, Netter JM. Endogeneity and the dynamics of internal corporate. Journal of Financial Economics 2012; 105 (3): 581-606.

67. Wooldridge MJ, Semykina A. Estimating panel data models in the presence of endogeneity and selection. Journal of Econometrics 2010; 157(2): 375-380.

68. Zabria SM, Ahmadb K, Wah KK. Corporate governance practices and firm performance: evidence from top 100 public listed companies in Malaysia. Procedia Economics and Finance 2016; 35, 287 - 296. 